\title{
An Efficient Chemoenzymatic Process for Preparation of Ribavirin
}

\author{
Vladimir Sakharov, ${ }^{1}$ Sergey Baykov, ${ }^{1}$ Irina Konstantinova, ${ }^{2}$ \\ Roman Esipov, ${ }^{2}$ and Mikhail Dorogov ${ }^{1}$ \\ ${ }^{1}$ Ushinsky Yaroslavl State Pedagogical University, Yaroslavl 150000, Russia \\ ${ }^{2}$ Shemyakin-Ovchinnikov Institute of Bioorganic Chemistry, Russian Academy of Sciences, Moscow 117997, Russia \\ Correspondence should be addressed to Sergey Baykov; sergei.v.baikov@yandex.ru
}

Received 30 July 2015; Revised 11 October 2015; Accepted 26 October 2015

Academic Editor: M. G. Ierapetritou

Copyright ( 92015 Vladimir Sakharov et al. This is an open access article distributed under the Creative Commons Attribution License, which permits unrestricted use, distribution, and reproduction in any medium, provided the original work is properly cited.

\begin{abstract}
Ribavirin is an important antiviral drug, which is used for treatment of many diseases. The pilot-scale chemoenzymatic process for synthesis of the active pharmaceutical ingredient Ribavirin was developed with $32 \%$ overall yield and more than $99.5 \%$ purity. The described method includes the chemical synthesis of 1,2,4-triazole-3-carboxamide, which is a key intermediate and enzymecatalyzed transglycosylation reaction for preparation of the desired product. 1,2,4-Triazole-3-carboxamide was synthesized from 5-amino-1,2,4-triazole-3-carboxylic acid by classical Chipen-Grinshtein method. Isolated from E. coli BL21(DE3)/pERPUPHHO1 strain the purine nucleoside phosphorylase was used as a biocatalytical system. All steps of this process were optimized and scaled.
\end{abstract}

\section{Introduction}

Antiviral properties of $1-\beta$ - $D$-ribofuranosyl-1- $H$-1,2,4-triazole-3-carboxamide or Ribavirin were described in 1972 for the first time [1]. Since that moment it is used in the treatment of influenza, severe respiratory syncytial virus (RSV) infection, and Lassa fever virus infection [1]. In combination with interferon- $\alpha$, it is a current standard for hepatitis $\mathrm{C}$ virus (HCV) therapy [1]. This disease was determined by World Health Organization (WHO) as one of the most important problems of health care. Chronic form of HVC is the main reason for causing liver cirrhosis and hepatocellular carcinoma [2]. There are 150 million infected people in the world and every year their number increases by about 34 millions [3]. Therefore, the development of the reliable and effective technology for Ribavirin production is a topical problem.

All the methods for synthesis of Ribavirin available at the moment could be divided into chemical [4-7] and microbiological [8-16] approaches. Typical procedure for chemical synthesis includes condensation of the 1,2,3,5-tetra- $O$-acetyl$\beta$ - $D$-ribofuranose $\mathbf{1}$ with 1,2,4-triazolecarboxylic acid esters $\mathbf{2}$ followed by treatment of the resulting compound $\mathbf{3}$ with methanolic ammonia solution (Scheme 1). Starting material, 1,2,3,5-tetra-O-acetyl- $\beta$ - $D$-furanose $\mathbf{1}$, can be prepared under acid-catalyzed acetylation of inosine, or of the other natural occurring nucleosides. In general, chemical methods have pure yield, high consumption of starting materials, and reagents, and an amount of toxic waste must be utilized.

That is why microbiological methods are considered more efficient. Nucleoside phosphorylase (NP) plays the key role in these methods. It catalyzes transfer of sugar moiety from one heterocyclic base to another. The bacterial $[9,14]$ or isolated enzymes are used for nucleoside synthesis $[17,18]$. The main disadvantages of this approach are low productivity and high costs of enzymes and starting materials.

Our technology of Ribavirinsynthesis combines the microbiological method for generation of the target structure with the chemical synthesis of key intermediates. This approach gives high level of reliability and efficiency while producing less toxic waste.

\section{Experimental}

2.1. Chemicals and Reagents. The starting reagents and solvents were obtained from Sigma-Aldrich Company and used 


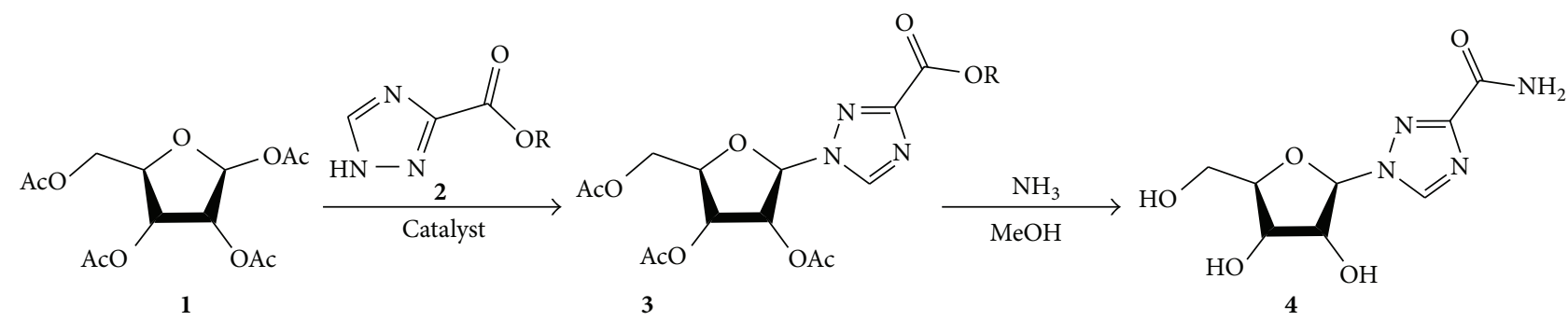

SCHEMe 1

as received. Purine nucleoside phosphorylase (protein concentration determined by Bradford assay, $15 \mathrm{mg} / \mathrm{mL}$; activity, 52 units/mg of protein) was obtained in the group of recombinant proteins (Institute of Bioorganic Chemistry, Russian Academy of Sciences, supervisor Dr. Esipov) [19].

2.2. Methods. The reactions were monitored by highperformance liquid chromatography (HPLC). Analysis was performed on Shimadzu LC 20 Prominence apparatus and Waters Xbridge C18, $50 \mathrm{~mm} \times 4.6 \mathrm{~mm}$ column with wateracetonitrile eluent. The purity of compounds and the yield of the target products were also determined by HPLC. ${ }^{1} \mathrm{H}$ NMR spectra were recorded on a Bruker DRX500 (500 MHz) and were determined in DMOS- $d_{6} \cdot{ }^{13} \mathrm{C}$ NMR spectra were recorded at $125 \mathrm{MHz}$. Chemical shifts are reported in parts per million relative to the peak of tetramethylsilane (TMS) (0.00 ppm). Melting points were measured on Mel-Temp 3.0.

2.3. Preparation of 1,2,4-Triazole-3-carboxylic Acid (7). To a suspension of $8.25 \mathrm{~kg}(64.5 \mathrm{~mol}) 5$-amino-1,2,4-triazole3-carboxylic acid 5 in $50.0 \mathrm{~L}$ water $1.9 \mathrm{~L}$ concentrated hydrochloric acid was added. The suspension was heated at $70^{\circ} \mathrm{C}$ to dissolve. The solution was cooled to room temperature and $30 \mathrm{~kg}$ of ice was added. Further ice-cold solution of $8.75 \mathrm{~kg}(126.8 \mathrm{~mol})$ sodium nitrite in $19.0 \mathrm{~L}$ of water was added. Following the addition the reaction mixture was stirred $30 \mathrm{~min}$ at $0-10^{\circ} \mathrm{C}$ and $40 \mathrm{~min}$ at room temperature. The resulting suspension was filtered and washed in ice water $(2 \times 250 \mathrm{~mL})$ to give $11.25 \mathrm{~kg}$ of diazonium salt 6 , which was used in the next step without further purification.

To a suspension of $3.75 \mathrm{~kg}(21.25 \mathrm{~mol})$ diazonium salt 6 in $25.0 \mathrm{~L}$ of methanol $10 \mathrm{~g}$ of sodium borohydride was added at $0-4^{\circ} \mathrm{C}$ (exothermic). The reaction mixture was cooled to $0-$ $4^{\circ} \mathrm{C}$ and procedure was repeated two times. After completion, the reaction mixture was refluxed $5 \mathrm{~min}$, cooled to $0-2^{\circ} \mathrm{C}$ over $20-25 \mathrm{~min}$, and filtered. The precipitate was washed with $6.5 \mathrm{~L}$ of cool methanol and $4.75 \mathrm{~kg}$ (65\%) of 1,2,4-triazole-3carboxylic acid 7 was obtained, as a white solid, $\mathrm{mp} 136-137^{\circ} \mathrm{C}$. ${ }^{1} \mathrm{H}$ NMR $\left(500 \mathrm{MHz}, \mathrm{DMOS}-d_{6}\right) \delta: 8.67(1 \mathrm{H}, \mathrm{s}), 14.01-14.52$ (1H, bs). ${ }^{13} \mathrm{C}$ NMR (125 MHz, DMOS- $\left.d_{6}\right) \delta: 148.5,151.9,165.6$. Found, \%: C 31.44; H 2.79; N 36.98. Calculate, \%: C 31.87; H 2.67; N 37.16.

2.4. Preparation of 1,2,4-Triazole-3-carboxylic Acid Methyl Ester (2). A hydrogen chloride gas was purged through the cooled to $0-2^{\circ} \mathrm{C}$ suspension of $4.75 \mathrm{~kg}$ ( $\left.41.9 \mathrm{~mol}\right) 1,2,4-$ triazole-3-carboxylic acid 7 in $35.0 \mathrm{~L}$ of methanol over $8 \mathrm{~h}$.
After completion, reaction mixture was stirred at room temperature for over $48 \mathrm{~h}$. The resulting suspension was filtered and washed with $3.5 \mathrm{~L}$ cool methanol. Product was obtained as a white solid, yield $4.68 \mathrm{~kg}(88 \%), \mathrm{mp} 185-186^{\circ} \mathrm{C}$. ${ }^{1} \mathrm{H}$ NMR (500 MHz, DMOS- $\left.d_{6}\right) \delta: 3.85(3 \mathrm{H}, \mathrm{s}), 8.73(1 \mathrm{H}, \mathrm{s})$, 14.65 (1H, bs). ${ }^{13} \mathrm{C}$ NMR (125 MHz, DMOS- $\left.d_{6}\right) \delta: 52.1,145.2$, 145.5, 160.2. Found, \%: C 37.69; H 4.09; N 33.16. Calculate, \%: C 37.80 ; H 3.97; N 33.06 .

2.5. Preparation of 1,2,4-Triazole-3-carboxamide (8). To $25.0 \mathrm{~L}$ of $(162.2 \mathrm{~mol}) 25 \%$ aqueous ammonia $4.68 \mathrm{~kg}$ (36.8 mol) 1,2,4-triazole-3-carboxylic acid methyl ester 2 was added while stirring. The reaction mixture was refluxed $30 \mathrm{~min}$, cooled to $40^{\circ} \mathrm{C}$, and evaporated at reduced pressure to volume of $15.0 \mathrm{~L}$. The resulting suspension was cooled to $0-5^{\circ} \mathrm{C}$ over $2 \mathrm{~h}$ and filtered. After recrystallization from water, $3.51 \mathrm{~kg}(85 \%)$ of 1,2,4-triazole-3-carboxamide $\mathbf{8}$ was obtained, as a white solid, mp $224-228^{\circ} \mathrm{C}$. ${ }^{1} \mathrm{H}$ NMR $\left(500 \mathrm{MHz}, \mathrm{DMOS}-d_{6}\right) \delta: 7.49(1 \mathrm{H}, \mathrm{s}), 7.73(1 \mathrm{H}, \mathrm{s}), 8.65(1 \mathrm{H}$, s), $14.26-14.98(1 \mathrm{H}, \mathrm{bs}) .{ }^{13} \mathrm{C}$ NMR $\left(125 \mathrm{MHz}, \mathrm{DMOS}-d_{6}\right)$ $\delta$ : 144.6, 156.4, 160.1. Found, \%: C 32.20; H 3.49; N 49.86. Calculate, \%: C 32.15; H 3.60; N 49.98.

2.6. Preparation of 1- $\beta$-D-Ribofuranosyl-1,2,4-triazole-3-carboxamide (Ribavirin, 4). $20.4 \mathrm{~g}$ of potassium dihydrophosphate was dissolved in $10 \mathrm{~L}$ of distilled water. The $\mathrm{pH}$ of the solution was adjusted to 7.0 with $5 \mathrm{~N}$ solution of potassium hydroxide. To the buffer solution $7.8 \mathrm{~g}(0.07 \mathrm{~mol})$ 1,2,4-triazole-3-carboxamide 8, $42.5 \mathrm{~g}$ ( $0.15 \mathrm{~mol})$ guanosine $\mathbf{9}$, and $30 \mathrm{~mL}$ of PNP $(15 \mathrm{mg} / \mathrm{mL}, 52 \mathrm{ea} / \mathrm{mg}$ of protein) solution were added. The reaction mixture was thermostated at 52$55^{\circ} \mathrm{C}$ over $7 \mathrm{~d}$. The resulting solution was concentrated at reduced pressure to $1 / 2$ of volume and cooled to $4-8^{\circ} \mathrm{C}$. The precipitated guanine with guanosine traces were filtered out. The filtrate was passed through ion exchange resin (eluted with water). Solvent was evaporated at reduced pressure and $12.2 \mathrm{~g}(71 \%)$ of ribavirin was obtained with $98.6 \%$ purity. After recrystallization from ethanol, $11.1 \mathrm{~g}(65 \%)$ of ribavirin was obtained, as white solid, mp $175-178^{\circ} \mathrm{C}$. Purity is $99.5 \%$ by HPLC (Figure 1 and Table 3). ${ }^{1} \mathrm{H}$ NMR $(500 \mathrm{MHz}, \mathrm{DMOS}-$ $\left.d_{6}\right) \delta: 3.48-3.52(1 \mathrm{H}, \mathrm{m}), 3.60-3.65(1 \mathrm{H}, \mathrm{m}), 3.93(1 \mathrm{H}, \mathrm{m})$, $4.12(1 \mathrm{H}, \mathrm{m}), 4.37(1 \mathrm{H}, \mathrm{m}), 4.90(1 \mathrm{H}, \mathrm{t}, J=5.5 \mathrm{~Hz}), 5.19$ $(1 \mathrm{H}, \mathrm{d}, J=5.6 \mathrm{~Hz}), 5.57(1 \mathrm{H}, \mathrm{d}, J=5.7 \mathrm{~Hz}), 5.82(1 \mathrm{H}, \mathrm{d}$, $J=3.8 \mathrm{~Hz}), 7.59(1 \mathrm{H}, \mathrm{s}), 7.80(1 \mathrm{H}, \mathrm{s}), 8.86(1 \mathrm{H}, \mathrm{s}), 14.26-$ 14.98 (1H, bs). ${ }^{13} \mathrm{C}$ NMR (125 MHz, DMOS- $\left.d_{6}\right) \delta: 61.1,69.8$, 74.5, 85.5, 92.0, 145.0, 151.4, 156.1. Found, \%: C 39.41; H 4.83; N 22.99. Calculate, \%: C 39.35; H 4.95; N 22.94. 


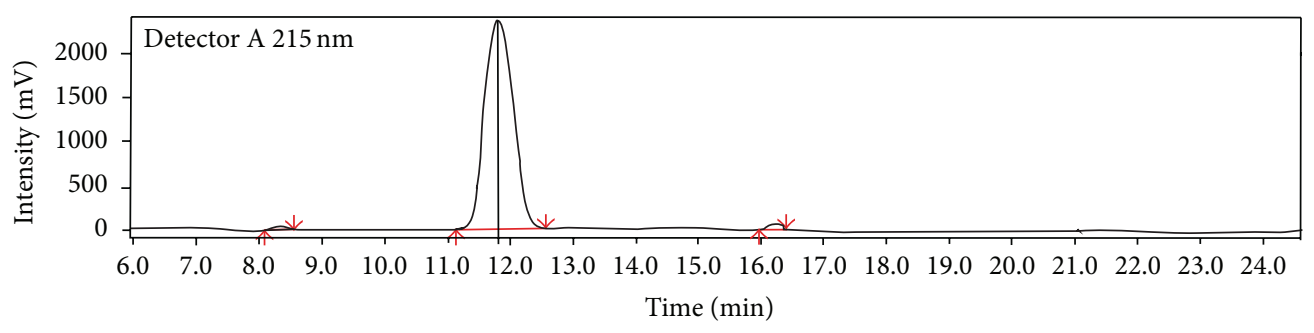

FIGURE 1: Typical chromatogram of the obtained Ribavirin.

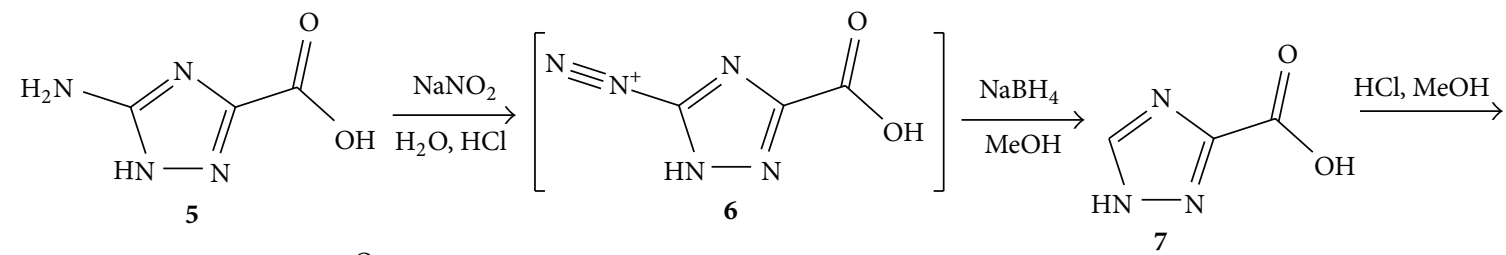<smiles>CCOC(=O)c1nc[nH]n1</smiles>

SCHEME 2

TABLE 1: Optimization of transglycosylation condition.

\begin{tabular}{lcccc}
\hline No. & Nucleoside & $\begin{array}{c}\text { Ratio } \\
\text { TCA/nucleoside }\end{array}$ & Time, h & $\begin{array}{c}\text { Yield of } \\
\text { Ribavirin, \% }\end{array}$ \\
\hline 1 & Guo & $1: 1$ & 120 & 50 \\
2 & Guo & $1: 1$ & 360 & 84 \\
3 & Ino & $1: 1$ & 120 & 45 \\
4 & Ino & $1: 1$ & 360 & 60 \\
5 & Guo & $1: 2$ & 120 & 97 \\
6 & Guo & $1: 3$ & 120 & 97 \\
7 & Guo & $1: 5$ & 120 & 98 \\
8 & Guo & $1: 15$ & 120 & 99 \\
\hline
\end{tabular}

\section{Results and Discussion}

It was previously reported that 1,2,4-triazolecarboxylic acid esters are not PNP substrate [20]. Therefore, only 1,2,4triazole-3-carboxamide 8 (TCA) could be used as a free heterocyclic base in Ribavirin synthesis. Thereby our first goal was to find out the most convenient and efficient way for chemical synthesis of TCA $\mathbf{8}$, which could be used in industry. After analysis of the literature we have chosen the classical Chipen-Grinshtein method [21], represented in Scheme 2.

The entire process is suitable for $\mathrm{kg}$-scale preparation. The yields of intermediates at each stage were not less than $65 \%$, and the overall yield of TCA 8 was $49 \%$.

There are two described approaches to microbiological synthesis of Ribavirin 4 from TCA: enzymatic (exogenic) [9] and fermentative (endogenic) [8]. In keys of exogenic approach all the components of the reaction systems should be added separately. Transglycosylation reaction, that is,
TABLE 2: The Ribavirin synthesis with different biocatalytical systems.

\begin{tabular}{lccc}
\hline Donor & Biocatalyst & $\begin{array}{c}\text { Conversion, } \\
\%\end{array}$ & Reference \\
\hline Uridine & A. hydrophila CECT4226 & 65 & {$[9]$} \\
Guanosine & GA-E. coli BMT 4D/1A & 70 & {$[10]$} \\
Uridine & pET-30a- $u$ dp-deoD & 84 & {$[14]$} \\
Uridine & ATCC 12407 & 86 & {$[16]$} \\
Guanosine & BL21(DE3)/pERPUPHHO1 & 97 & This study \\
\hline
\end{tabular}

transfer glycoside moiety from nucleoside (donor) to free purine base (acceptor), is an example of this kind of reactions. During endogenic catalysis the substrate should be added to bacterial culture [8].

Transglycosylation reaction (Scheme 3) was chosen, because it is better studied and easy to control. Purified enzyme, the purine nucleoside phosphorylase (PNP), which was isolated from Escherichia coli (E. coli) BL21(DE3)/pERPUPHHO1 strain, was used as a biocatalytical system.

Natural nucleoside guanosine (Guo) 9 was chosen as ribose donor, because of sedimentation of product guanine (Gua) 10 during the reaction, causing the equilibrium shift in favor of the required product. In addition, Guo 9 is commercially available, which is an important fact for the industrial application. The optimal ratio of Guo 9 to TCA 8 was also studied. The results are shown in Table 1.

In accordance with this data, the $97 \%$ conversion of TCA 8 into the Ribavirin 4 can be achieved when using 2 mol of Guo 9 per one mol of 8. Further increase of Guo 9 excess did not improve the conversion rate. In addition, comparison with described biocatalysts is shown in Table 2 . 
<smiles>NC(=O)c1ncn(C2OC(CO[C@@H](O)[PH2+][PH3])[C@@H](O)[C@H]2O)n1</smiles>

SCHEME 3

TABLE 3

\begin{tabular}{|c|c|c|c|c|c|c|c|c|c|}
\hline Peak\# & Ret. Time & Area & Area $\%$ & Height & Mark & Conc. & Unit & ID\# & Name \\
\hline 1 & 8.351 & 15549 & 0.024 & 946 & $\mathrm{M}$ & 0.024 & & & \\
\hline 2 & 11.804 & 64132634 & 99.950 & 2160366 & & 99.950 & & & \\
\hline 3 & 16.180 & 16757 & 0.026 & 2019 & M & 0.026 & & & \\
\hline Total & & 64164940 & 100.00 & 2163331 & & 100.00 & & & \\
\hline
\end{tabular}

The process was scaled from $0.5 \mathrm{~L}$ volume to $20 \mathrm{~L}$ volume. In order to achieve $97 \%$ conversion the reaction time was extended from 120 to $168 \mathrm{~h}$. Residual TCA 8 was removed during chromatographic purification and recrystallization. Typical chromatogram of the obtained Ribavirin is shown in Figure 1 and Table 3. TCA 8 (0.434\%, RT $16.180 \mathrm{~min})$ and Guo $9(0.026 \%$, RT $8.351 \mathrm{~min})$ is main impurity.

The use of soluble enzyme is the main limitation for industrial application of this process. Therefore, further efforts will be focused on the development of immobilized enzyme. Recently, Rivero et al. reported successful immobilization of E. coli ATCC 12407 in agarose matrix [16]. Moreover, immobilization on fused silica Open Tubular Capillary [22], aldehyde-agarose [23], and MagReSyn epoxide microspheres [24, 25], in calcium alginate, agar, and $\mathrm{k}$ carrageenan matrix [18], was described in the literature. Thus, we believe, that the immobilisation of our enzyme is possible.

\section{Conclusions}

To conclude, we have found an efficient combined chemoenzymatic method of Ribavirin synthesis from commercially available materials. We have adapted previously reported laboratory protocol of 1,2,4-triazole-3-carboxamide chemical synthesis to kilograms scale. Purity of the final product is sufficient to use as an active pharmaceutical ingredient. The reported approach is superior in comparison with the earlier chemical methods and approaches. In the future, we plan to immobilize the enzyme for further improvement of the technology.

\section{Conflict of Interests}

The authors declare that there is no conflict of interests regarding the publication of this paper.

\section{Acknowledgments}

This study was supported by Russian Federation Government Decree no. 218 of April 9, 2010 (contract no. 02.G25.31.0019, code 2012-218-03-258) for the project "Establishing Production of Import-Replacing Active Pharmaceutical Ingredients Based on Innovative Technologies, Enzymatic Synthesis and Biocatalysis" conducted by CJSC "R-Pharm" and The Ushinsky Yaroslavl State Pedagogical University.

\section{References}

[1] S. Crotty, D. Maag, J. J. Arnold et al., "The broad-spectrum antiviral ribonucleoside ribavirin is an RNA virus mutagen," Nature Medicine, vol. 6, no. 12, pp. 1375-1379, 2000.

[2] S. Mohammadzadeh, F. Roohvand, A. Memamejadian et al., "Co-expression of hepatitis C virus polytope-HBsAg and p19silencing suppressor protein in tobacco leaves," Pharmaceutical Biology, 2015.

[3] M.-H. Lee, H.-I. Yang, Y. Yuan, G. L'Italien, and C.-J. Chen, "Epidemiology and natural history of hepatitis C virus infection," World Journal of Gastroenterology, vol. 20, no. 28, pp. 92709280, 2014.

[4] J. T. Witkowski, R. K. Robins, R. W. Sidwell, and L. N. Simon, "Design, synthesis, and broad spectrum antiviral activity of 1- $\beta$-D-ribofuranosyl-1,2,4-triazole-3-carboxamide and related nucleosides," Journal of Medicinal Chemistry, vol. 15, no. 11, pp. 1150-1154, 1972.

[5] M. D. A. Brancale, L. Naesens, J. Neyts, M. Derudas, J. Balzarini, and C. McGuigan, "Application of the phosphoramidate ProTide approach to the antiviral drug ribavirin," Bioorganic and Medicinal Chemistry, vol. 18, no. 7, pp. 2748-2755, 2010.

[6] Y. S. Li, J. J. Zhang, L. Q. Mei, and C. X. Tan, "An improved procedure for the preparation of ribavirin," Organic Preparations and Procedures International, vol. 44, no. 4, pp. 387-391, 2012.

[7] W.-Y. Liu, H.-Y. Li, B.-X. Zhao, D.-S. Shin, S. Lian, and J.Y. Miao, "Synthesis of novel ribavirin hydrazone derivatives and anti-proliferative activity against A549 lung cancer cells," Carbohydrate Research, vol. 344, no. 11, pp. 1270-1275, 2009. 
[8] Y. Ma, Sh. Yang, L. Liu et al., "Fermentative production of ribavirin by overexpressing purine nucleoside phosphorylase in Bacillus," Journal of Chemical and Pharmaceutical Research, vol. 6, no. 5, pp. 1377-1384, 2014.

[9] M. Nbile, M. Terreni, E. Lewkowicz, and A. M. Iribarren, "Aeromonas hydrophila strains as biocatalysts for transglycosylation," Biocatalysis and Biotransformation, vol. 28, no. 5-6, pp. 395-402, 2010.

[10] V. N. Barai, A. I. Zinchenko, L. A. Eroshevskaya, E. N. Kalinichenko, T. I. Kulak, and I. A. Mikhailopulo, "A universal biocatalyst for the preparation of base- and sugar-modified nucleosides via an enzymatic transglycosylation," Helvetica Chimica Acta, vol. 85, no. 7, pp. 1901-1908, 2002.

[11] N. Chen, C.-G. Xing, X.-X. Xie, and Q.-Y. Xu, "Optimization of technical conditions of producing ribavirin by Bacillus subtilis," Annals of Microbiology, vol. 59, no. 3, pp. 525-530, 2009.

[12] M. Taverna-Porro, L. A. Bouvier, C. A. Pereira, J. M. Montserrat, and A. M. Iribarren, "Chemoenzymatic preparation of nucleosides from furanoses," Tetrahedron Letters, vol. 49, no. 16, pp. 2642-2645, 2008.

[13] M. V. Chudinov, I. D. Konstantinova, O. I. Ryzhova et al., "A new effective method for the synthesis of 1,2,4-triazole-3carboxamide and ribavirin derivatives," Pharmaceutical Chemistry Journal, vol. 39, no. 4, pp. 212-215, 2005.

[14] Q.-B. Ding, L. Ou, D.-Z. Wei, X.-K. Wei, Y.-M. Xu, and C.Y. Zhang, "Enzymatic synthesis of nucleosides by nucleoside phosphorylase co-expressed in Escherichia coli," Journal of Zhejiang University: Science B, vol. 11, no. 11, pp. 880-888, 2010.

[15] J. A. Trelles, J. Fernández-Lucas, L. A. Condezo, and J. V. Sinisterra, "Nucleoside synthesis by immobilised bacterial whole cells," Journal of Molecular Catalysis B: Enzymatic, vol. 30, no. 5-6, pp. 219-227, 2004.

[16] C. W. Rivero, E. C. De Benedetti, M. E. Lozano, and J. A. Trelles, "Bioproduction of ribavirin by green microbial biotransformation," Process Biochemistry, vol. 50, no. 6, pp. 935-940, 2015.

[17] H. Komatsu and T. Araki, "Efficient chemo-enzymatic syntheses of pharmaceutically useful unnatural 2 -deoxynucleosides," Nucleosides, Nucleotides and Nucleic Acids, vol. 24, no. 5-7, pp. 1127-1130, 2005.

[18] W. Luo, Y. Liu, X. Zhu et al., "Cloning and characterization of purine nucleoside phosphorylase in Escherichia coli and subsequent ribavirin biosynthesis using immobilized recombinant cells," Enzyme and Microbial Technology, vol. 48, no. 6-7, pp. 438-444, 2011.

[19] R. S. Esipov, A. I. Gurevich, D. V. Chuvikovsky, L. A. Chupova, T. I. Muravyova, and A. I. Miroshnikov, "Overexpression of Escherichia coli genes encoding nucleoside phosphorylases in the pET/BI21(DE3) system yields active recombinant enzymes," Protein Expression and Purification, vol. 24, no. 1, pp. 56-60, 2002.

[20] I. D. Konstantinova, M. V. Chudinov, I. V. Fateev et al., "Chemoenzymatic method of 1,2,4-triazole nucleoside synthesis: possibilities and limitations," Russian Journal of Bioorganic Chemistry, vol. 39, no. 1, pp. 53-71, 2013.

[21] G. I. Chipen and V. Y. Grinshtein, "A new method of preparing 1, 2, 4-triazole carboxylic-3 acids," Chemistry of Heterocyclic Compounds, vol. 1, no. 4, pp. 420-421, 1966.

[22] E. Calleri, D. Ubiali, I. Serra et al., "Immobilized purine nucleoside phosphorylase from Aeromonas hydrophila as an on-line enzyme reactor for biocatalytic applications," Journal of Chromatography B, vol. 968, pp. 79-86, 2014.
[23] I. Serra, D. Ubiali, J. Piškur et al., "Developing a collection of immobilized nucleoside phosphorylases for the preparation of nucleoside analogues: enzymatic synthesis of arabinosyladenine and $2^{\prime}, 3^{\prime}$-dideoxyinosine," ChemPlusChem, vol. 78, no. 2 , pp. 157-165, 2013.

[24] X. Zhou, K. Szeker, L.-Y. Jiao, M. Oestreich, I. A. Mikhailopulo, and P. Neubauer, "Synthesis of 2,6-dihalogenated purine nucleosides by thermostable nucleoside phosphorylases," Advanced Synthesis \& Catalysis, vol. 357, no. 6, pp. 1237-1244, 2015.

[25] X. Zhou, I. A. Mikhailopulo, M. N. Cruz Bournazou, and P. Neubauer, "Immobilization of thermostable nucleoside phosphorylases on MagReSyn epoxide microspheres and their application for the synthesis of 2,6-dihalogenated purine nucleosides," Journal of Molecular Catalysis B: Enzymatic, vol. 115, pp. 119-127, 2015. 

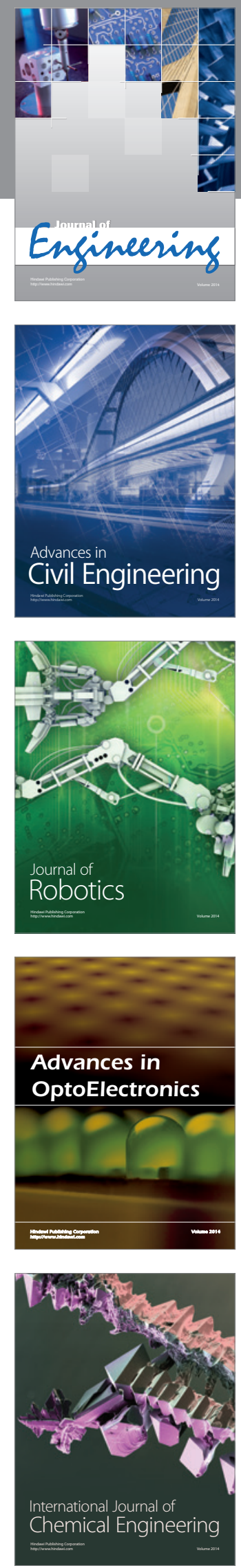

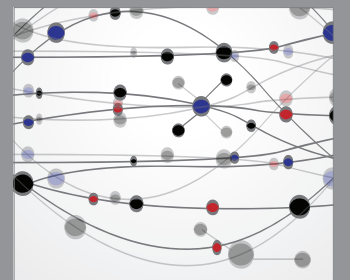

The Scientific World Journal
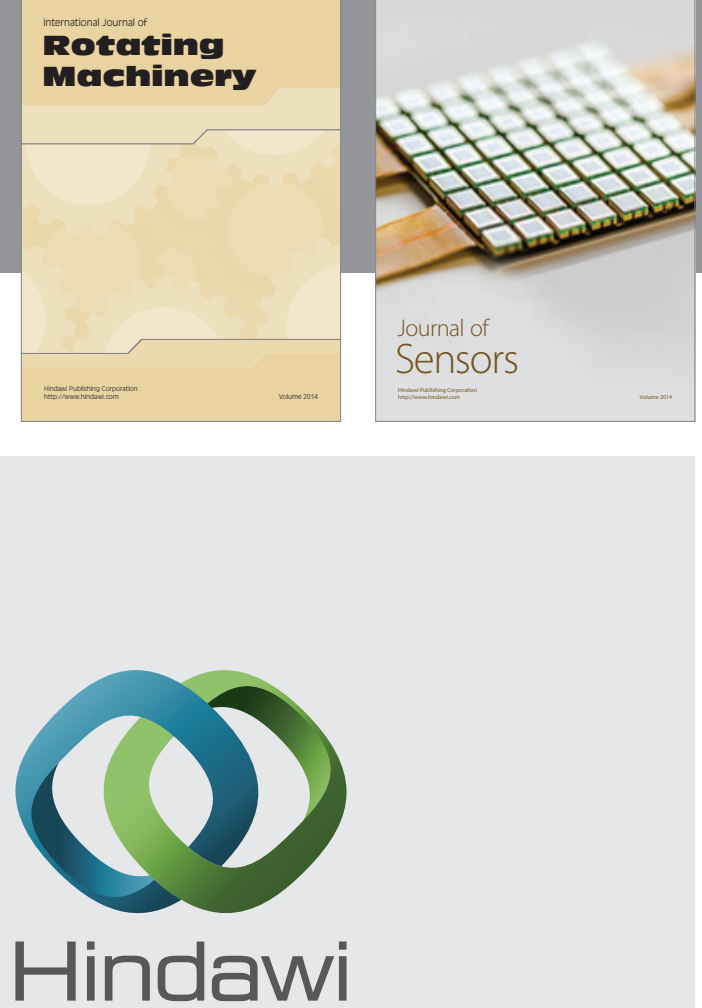

Submit your manuscripts at http://www.hindawi.com
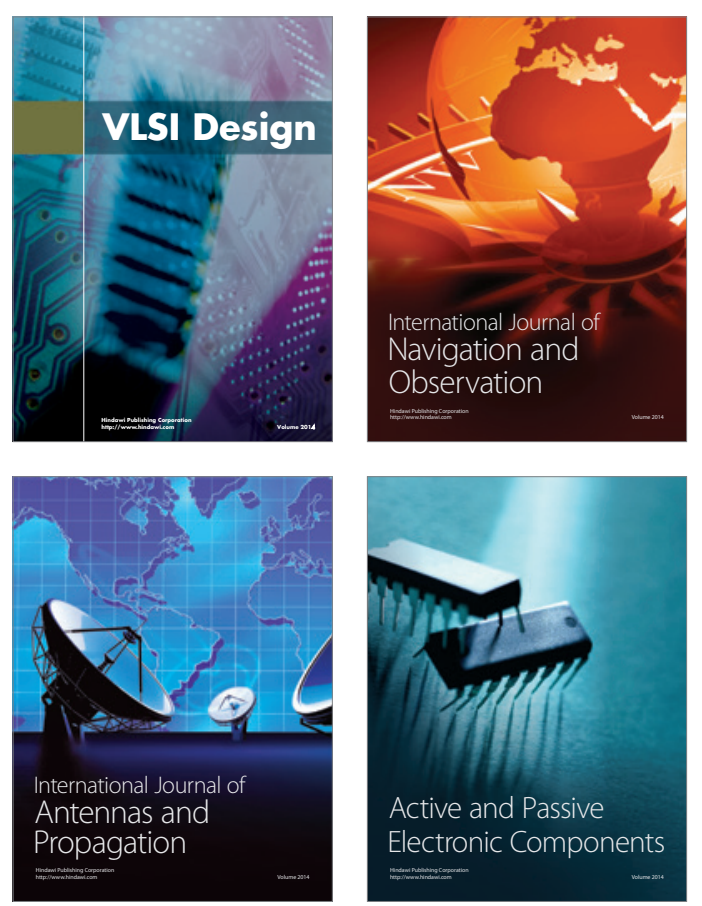
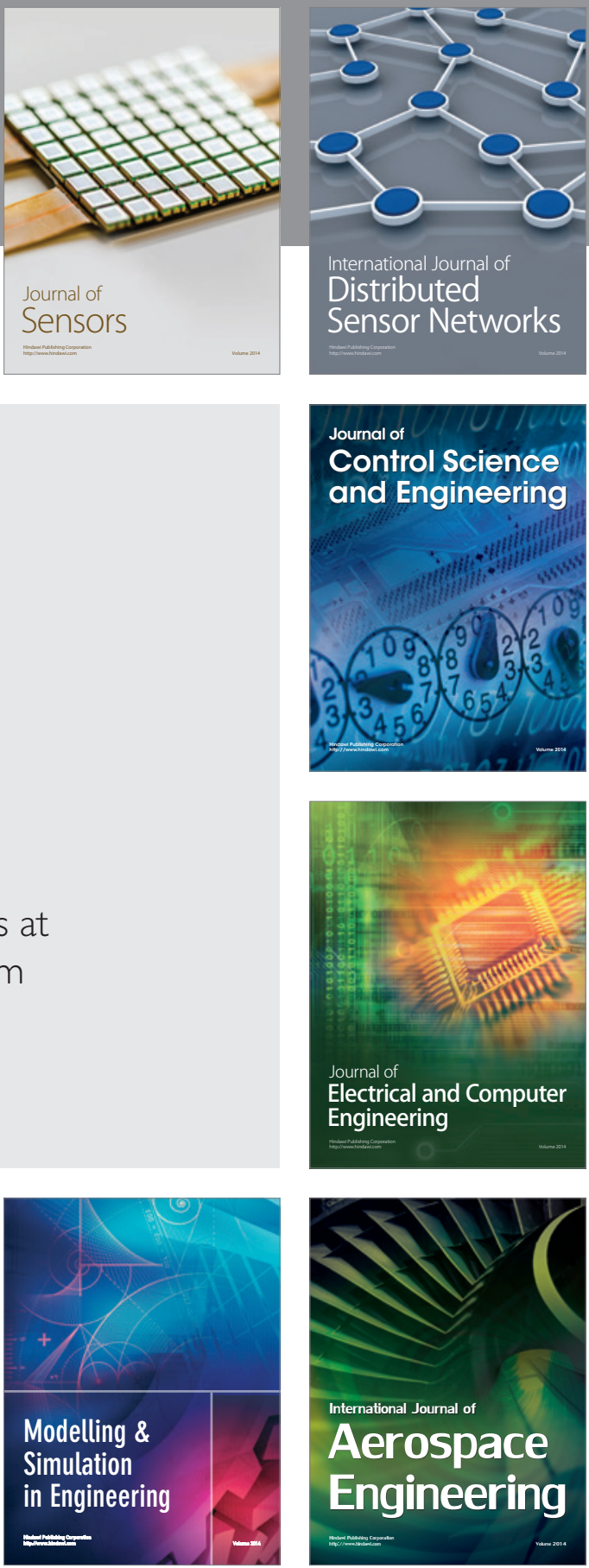

Journal of

Control Science

and Engineering
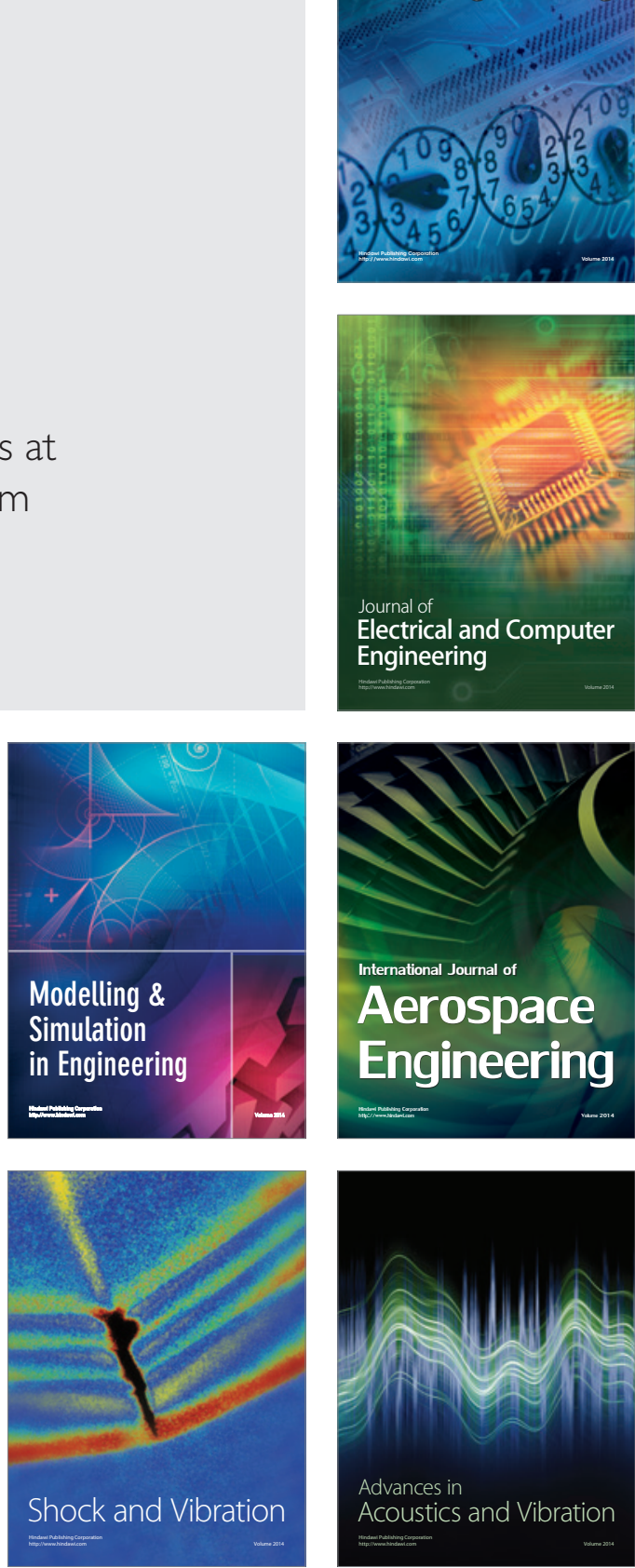